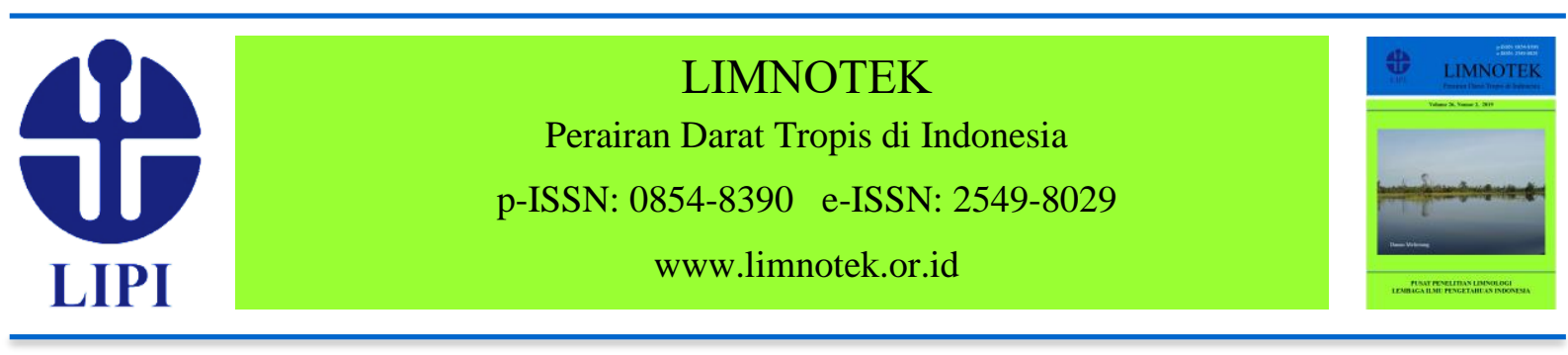

\title{
Neraca Air Situ Cikaret dan Situ Kabantenan di Kabupaten Bogor Menggunakan Pemodelan Hidrologi SWAT
}

\section{Claudia Tyas Nugraheni ${ }^{1, *}$, Hidayat Pawitan ${ }^{2}$, Yanuar Jarwadi Purwanto ${ }^{3}$, Iwan Ridwansyah ${ }^{4}$}

\author{
${ }^{1}$ Sekolah Pascasarjana, Institut Pertanian Bogor, \\ ${ }^{2}$ Departemen Geofisika dan Meteorologi, FMIPA, Institut Pertanian Bogor, \\ ${ }^{3}$ Departemen Teknik Sipil dan Lingkungan, Fakultas Pertanian, Institut Pertanian Bogor, \\ ${ }^{4}$ Pusat Penelitian Limnologi, Lembaga Ilmu Pengetahuan Indonesia
}

Email: Claudiatyas@gmail.com

Diajukan 3 Desember 2018. Ditelaah 20 Desember 2018. Disetujui 23 April 2019.

\begin{abstract}
Abstrak
Pembangunan kota yang pesat di Kabupaten Bogor telah menyebabkan 39 situ dari 95 danau kecil perkotaan mengalamai kerusakan. Penelitian ini menganalisis neraca air situ untuk memberikan gambaran volume air yang dapat ditampung. Model hidrologi SWAT (Soil and Water Assesment Tools) merupakan model hidrologi yang dirancang untuk memprediksi dampak penggunaan lahan dan manajemen terhadap air, sedimen, dan hasil kimia pertanian di Daerah Aliran Sungai (DAS). Model SWAT digunakan dalam penelitian ini untuk menyimulasikan neraca air Situ Kabantenan dan Situ Cikaret. Model berhasil menyimulasikan neraca air selama periode 2008-2015 dengan data tutupan lahan tahun 2014. Kalibrasi model dilakukan pada tahun 2014 dengan nilai $\mathrm{R}^{2}$ dan NSE sebesar 0,58 dan 0,55. Validasi model dilakukan pada tahun 2013 dengan nilai $\mathrm{R}^{2}$ dan NSE sebesar 0,54 dan 0,49. Volume bulanan rata-rata Situ Kabantenan dan Situ Cikaret selama tahun 2008-2015 sebesar $136.955 \mathrm{~m}^{3}$ dan $508.907 \mathrm{~m}^{3}$. Inflow tahunan rata-rata sebesar $24.693 .822 \mathrm{~m}^{3} /$ tahun dan outflow sebesar $25.177 .593 \mathrm{~m}^{3} /$ tahun, presipitasi sebesar $648.520 \mathrm{~m}^{3} /$ tahun, evaporasi sebesar $166.543 \mathrm{~m}^{3} /$ tahun, delta storage $1.794 \mathrm{~m}^{3} /$ tahun. Debit inflow rata-rata di outlet Situ Cikaret (20082015) sebesar $0,78 \mathrm{~m}^{3} / \mathrm{sekon}$ dan debit outflow sebesar $0,80 \mathrm{~m}^{3} / \mathrm{sekon}$. Hasil neraca air menunjukkan kedua situ dalam kondisi baik karena tidak pernah melewati emergency spillway, tetapi fungsinya perlu dioptimumkan sebagai pengendali banjir di DAS Ciliwung. Penelitian ini juga menunjukkan bahwa model SWAT dapat dijadikan sebagai alat monitoring, khususnya untuk danau kecil perkotaan sebagai tempat penampung air.
\end{abstract}

Kata kunci: Situ Cikaret, Situ Kabantenan, neraca air, model SWAT

\begin{abstract}
Water Balance of Situ Cikaret and Situ Kabantenan in Bogor Regency Using SWAT Hydrological Modeling. Bogor regency which is located in the middle of the Ciliwung basin centered in Cibinong city is experiencing rapid urban development. However, with the rapid urban
\end{abstract}


development, most of these small lakes in either disappear or in degraded conditions. In this area presently still maintain 95 urban small lakes or locally known as 'situ'. Situ has multifunction such as water retention for flood mitigation, irrigation for urban agriculture, fisheries, water sport activities, and ecotourism. The objective of this study was to analyze the water balance of situ. The model was calibrated and validated on the Kampung Kelapa river gauge with manual calibration. The Soil Water Assesment Tool (SWAT) is a hydrological model designed to predict the impact of land use and management on water, sediment and agricultural chemical yields in watersheds, The model was applied to Situ Kabantenan and Cikaret for modeling of the hydrological water balance. The SWAT model simulation was done for the periods of 2008-2015 while it used land use information in 2014. The Calibration was done in 2014 and the validation in 2013, the $\mathrm{R}^{2}$ and Nash Sutcliffe Efficiency (NSE) of the calibration were 0,58 and 0,55 respectively and the validations were 0,54 and 0,49 respectively. The monthly average of volume of Situ Kabantenan and Situ Cikaret from the simulation were $136,955 \mathrm{~m}^{3}$ and 508,907 $\mathrm{m}^{3}$, respectively. The annual inflow of Situ Cikaret was $24,693,822 \mathrm{~m}^{3} /$ year and outflow was $25,177,593 \mathrm{~m}^{3} /$ year, precipitation was $648,520 \mathrm{~m}^{3} /$ year, evaporation was $166,543 \mathrm{~m}^{3} /$ year, delta storage $1,794 \mathrm{~m}^{3} /$ year, respectively. The average inflow discharge of Situ Cikaret (2008-2015) were $0.78 \mathrm{~m}^{3} / \mathrm{s}$ and outflow discharge was $0.80 \mathrm{~m}^{3} / \mathrm{s}$. The water balance results showed that both sites were in good condition since they have never passed the emergency spillway, but their function needs to be optimized as a flood controller in the Ciliwung Watershed. This study also showed that the SWAT model can be utilized as a potential monitoring tool, especially for small urban lakes as water reservoirs.

Keywords: Situ Cikaret, Situ Kabantenan, water balance, SWAT model

\section{Pendahuluan}

Wilayah metropolitan Jabodetabek secara bentang alam terletak dari daerah dataran tinggi Gunung Gede Pangrango hingga daerah pesisir Laut Jawa di bagian utara. Jabodetabek menjadi wilayah perkotaan terbesar kedua di dunia dengan populasi total berjumlah 28 juta pada tahun 2010 (Pravitasari et al., 2015). Kondisi pembangunan perkotaan yang pesat saat ini memberikan tekanan pada daerah aliran sungai dan danau kecil pengendali banjir di perkotaan sebagai bagian dari sistem hidrologi kota. Dampak dari pembangunan yang terjadi antara lain peningkatan laju dan volume limpasan permukaan, daya infitrasi dan aliran dasar menjadi hilang yang pada akhirnya meningkatkan intensitas kejadian banjir (Fletcher et al., 2013).

Berbagai studi telah mengungkapkan bahwa permasalahan banjir di Jabodetabek terjadi karena alih fungsi kawasan resapan akibat urbanisasi dan penggundulan hutan, infrastruktur pengendali banjir kurang berfungsi. dan kapasitas sistem drainase perkotaan berkurang (Remondi et al., 2015; Rustiadi et al., 2012; Steinberg; 2007; Pawitan, 2002). Fenomena kejadian banjir di Jabodetabek dalam 20 tahun terakhir terjadi secara musiman dan meningkat pada musim penghujan, yaitu pada bulan Januari 1996, Februari 2002, Februari 2007, Februari 2008, Januari 2013, Januari dan Februari 2014 (BNPB, 2016; Remondi et al., 2015). Salah satu kejadian banjir di wilayah Jabodetabek adalah banjir di Kota Depok akibat peluapan Sungai Cikumpa, salah satu bagian dari DAS Ciliwung. Kejadian banjir ini memberikan dampak pada tiga perumahan di Kecamatan Sukmajaya pada tahun 2011. Kejadian banjir yang lebih parah pada bulan Maret 2016 menyebabkan ratusan rumah di Kecamatan Sukmajaya dan Kecamatan Cilodong terendam banjir hingga dua meter (Purnama, 2016).

Salah satu infrastruktur pengendali banjir yang kurang berfungsi dengan baik adalah danau kecil di perkotaan atau oleh masyarakat lokal dikenal dengan situ. Schuler dan Simpson (2001) mengemukakan tipologi situ berbeda dari danau alami, yaitu memiliki kriteria antara lain biasanya berukuran kecil, dangkal, hasil buatan manusia, dan daerah tangkapannya sangat berpengaruh pada daerah terbangun. Situ memiliki fungsi untuk menampung limpasan air permukaan yang dapat meredam laju debit puncak. Namun saat ini, banyak situ mengalami kerusakan dan bahkan hilang. Sebanyak 203 situ yang tersebar di Jabodetabek dari luas total $2.337,10$ ha telah mengalami penurunan luas menjadi $1.462,78$ ha (KLHK, 2014). Situ yang 
mengalami penurunan luas terbanyak terjadi di wilayah Bogor, Depok, Bekasi, dan Tangerang. Selain penurunan luas, hampir 10 sampai $>50 \%$ situ hilang dan mengalami penurunan daya tampung karena pendangkalan, ekspansi area pertanian ke zona litoral situ, sampah, ekspansi gulma, alih fungsi lahan tangkapan danau menjadi industri, transportasi, dan permukiman (Supriyadi et al., 2015; Henny \& Meutia; 2014; Rosnilla, 2004). Tidak seperti sistem perairan alami, situ dirancang untuk menerima limpasan air permukaan atau sebagai titik terakhir pengolahan air limpasan (Wong et al., 1999). Karena fungsinya tersebut, dampak dari limpasan air permukaan mengakibatkan penurunan kualitas air dan menyebabkan penurunan kualitas kesehatan di banyak ekosistem perkotaan.

Kabupaten Bogor merupakan salah satu kabupaten di Jabodetabek dengan jumlah situ terbanyak, yaitu 95 situ. Namun dari 95 situ yang ada, sebanyak 39 situ mengalami kerusakan, baik rusak ringan maupun rusak berat (KLHK, 2014). KLHK (2014) menjelaskan alih fungsi lahan menjadi lahan terbangun akibat urbanisasi mengakibatkan terjadi penurunan luas situ sebesar 15,39 ha di kabupaten ini dari tahun 2007 hingga tahun 2011. Bukti nyata terjadi urbanisasi di kabupaten ini adalah pertumbuhan penduduk dari 2,4 juta penduduk tahun 1980 menjadi 3,7 juta penduduk tahun 1990 dan terus bertambah menjadi 5,3 juta penduduk tahun 2014 (BPS 2016; Firman, 1997). Hal ini, bila tidak diantisipasi pada masa mendatang akan berpengaruh pada fungsi dan keberadaan situ di Kabupaten Bogor sebagai kawasan resapan yang akhirnya mengurangi daya tampung debit puncak banjir karena lokasinya yang berada di daerah hulu dan tengah empat aliran sungai (Sungai Ciliwung, Sungai Cisadane, Sungai Angke Pesanggrahan, dan Sungai Bekasi).

Saat ini sebagian besar penelitian tentang situ di Jabodetabek masih terpusat pada persebaran jumlah situ (Henny \& Meutia, 2014), aspek biologi (Marwoto et al., 2014), kualitas air (Henny \& Meutia, 2014; Kristiana, 2003) dan pengelolaan kelembagaan situ (Supriyadi et al., 2015). Penelitian mengenai situ sebagai salah satu bagian dari sistem hidrologi kota yang berfungsi sebagai pengendali banjir di wilayah Jabodetabek relatif masih sangat terbatas. Oleh karena itu, pemodelan neraca air situ dan daerah tangkapannya perlu dilakukan untuk memberikan gambaran kuantifikasi neraca air situ sebagai input pengelolaan situ dan daerah tangkapannya. Tujuan penelitian ini adalah untuk memperoleh neraca air situ yang memberikan gambaran volume air yang dapat ditampung di Situ Cikaret dan Situ Kabantenan.

\section{Bahan dan Metode}

\section{Lokasi Penelitian}

Penelitian ini dilaksanakan di subDAS Cikumpa, bagian dari DAS Ciliwung Tengah. SubDAS Cikumpa memiliki luas 2.529,63 ha (Gambar 1). Secara geografis, wilayah ini terletak di $106^{\circ} 21^{\prime}-107^{\circ} 13^{\prime}$ Bujur Timur and $6^{\circ} 19^{\prime}-6^{\circ} 47^{\prime}$ Lintang Selatan. Wilayah ini dipilih karena peran wilayah ini sebagai kawasan resapan dan program konservasi situ oleh Pemerintah Kabupaten Bogor dengan konsep Situ front City untuk peningkatan fungsi situ sebagai arena dayung internasional sekaligus meningkatkan kapasitas tampungan sebagai salah satu bentuk pengendalian banjir Sungai Ciliwung.

\section{Peralatan dan Analisis Neraca Air Situ}

Peralatan yang digunakan berupa Software ERDAS Imagine v14, ArcGIS v10.2, GPS, ArcSWAT versi 2012.10_3.18 Beta, Google Earth, Microsoft Office 2013. Data numerik dan data spasial yang digunakan dalam tahap ini yaitu:

1. Peta Digital Elevation Model (DEM) Jawa Barat beresolusi $30 \times 30 \mathrm{~m}^{2}$ dari Citra SRTM.

2. Peta Batas Daerah Aliran Sungai (DAS) Ciliwung Tengah skala 1:25.000 dari BPDAS Citarum-Ciliwung.

3. Peta jenis tanah skala tinjau 1:250.000 DAS Ciliwung dari Pusat Penelitian Tanah dan Agroklimat.

4. Peta tutupan lahan tahun 2014 dari Badan Planologi Kehutanan Kementerian Lingkungan Hidup dan Kehutanan.

5. Data iklim tahun 2007-2017 dari BMKG dan BBWS Ciliwung Cisadane berupa data curah hujan harian $(\mathrm{mm})$, data temperatur maksimum dan minimum harian $\left({ }^{\circ} \mathrm{C}\right)$, data kelembapan udara harian (\%), data radiasi matahari harian $\left(\mathrm{MJ} \mathrm{m} \mathrm{m}^{-2}\right.$ hari $\left.^{-1}\right)$, data kecepatan angin harian $\left(\mathrm{ms}^{-1}\right)$. 


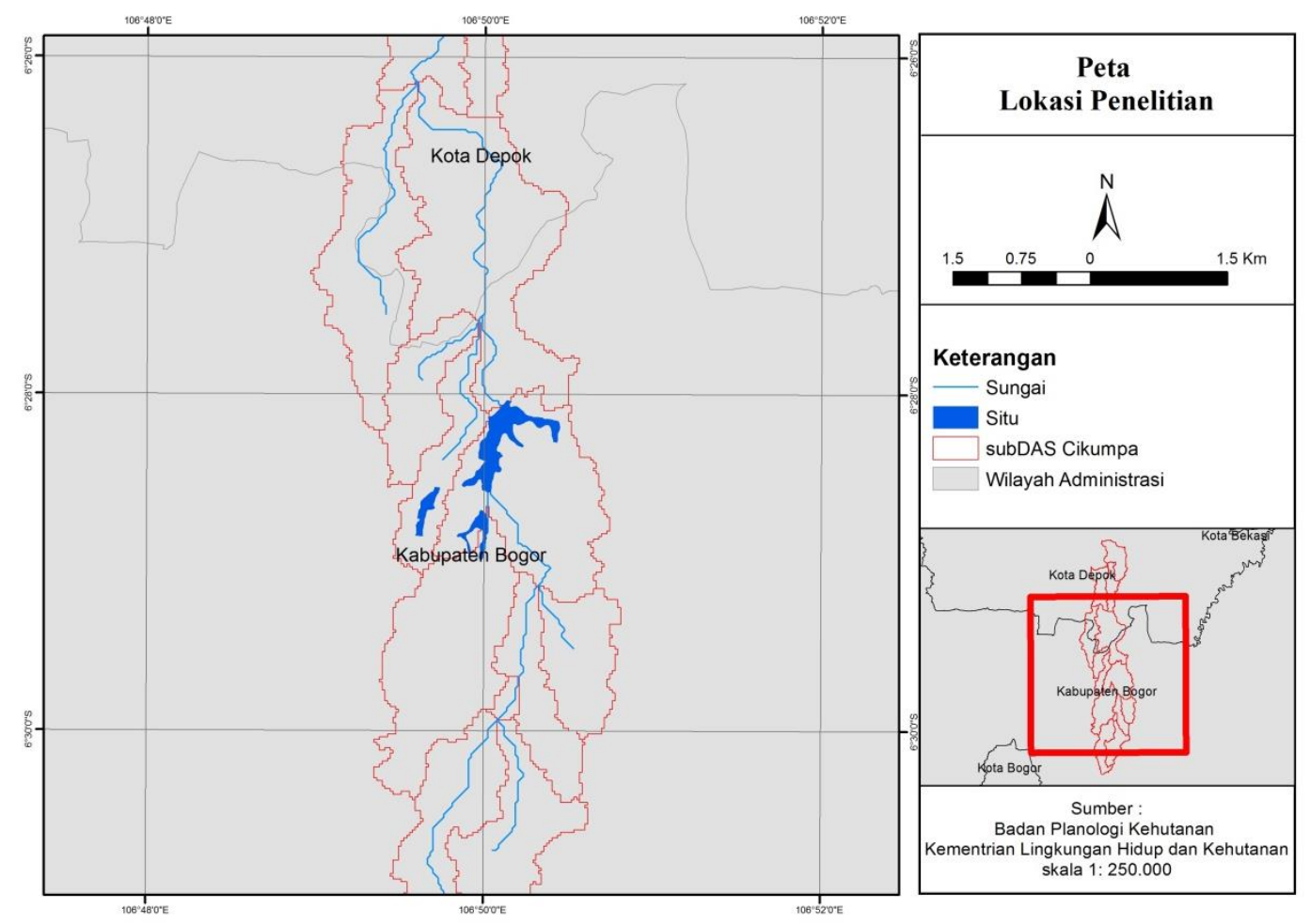

Gambar 1. Lokasi penelitian

6. Data Detail Engineering Desain (DED) penggabungan Situ Kabantenan dan Situ Cikaret dari BBWS Ciliwung Cisadane.

\section{Neraca Air Situ dengan Model SWAT}

Soil Water Assessment Tool (SWAT) adalah model spasial dan temporal yang dapat menyimulasi air, sedimen, nutrien, dan perpindahan bahan terlarut di daerah tangkapan dalam skala harian atau subharian. SWAT dapat terintegrasi langsung dengan GIS melalui ArcSWAT. Penggunaan model SWAT untuk menyimulasikan neraca air situ atau danau perkotaan diadopsi dari Setegn et al. (2008) yang menggunakan model SWAT untuk menyimulasi neraca air Danau Tana di Etiopia. Analisis neraca air situ digunakan untuk mengetahui perbedaan antara debit air yang masuk ke situ (debit inflow) dan yang keluar (debit outflow). Dengan demikian, apakah debit air dapat tertampung atau tidak dalam situ dapat dianalisis. Penghitungan ini akan memberikan gambaran tentang fungsi situ sebagai pengendali banjir. Dalam penghitungan sederhana, neraca air adalah perubahan antara input dan output selama waktu tertentu, baik dalam bentuk tampungan, dikonsumsi, ataupun keluar (Sigh et al., 2009). Komponen input dari neraca air di SWAT terdiri dari presipitasi
$\left(V_{p c p}\right)$, aliran masuk $\left(V_{\text {flow in }}\right)$, dan air tampungan awal $\left(\mathrm{V}_{\text {stored }}\right)$, sementara komponen output terdiri dari evaporasi $\left(\mathrm{V}_{\text {evap }}\right)$, aliran keluar $\left(\mathrm{V}_{\text {flow }}\right.$ out ) dan air yang hilang dari badan air $\left(\mathrm{V}_{\text {seep }}\right)$ (Neitsch et al., 2009). Siklus hidrologi yang disimulasikan oleh SWAT didasarkan pada persamaan (1) neraca air untuk waduk.

$\mathrm{V}=$ Vstored + Vflow in - Vflow out +

V pcp - Vevap - Vseep

dengan $\mathrm{V}$ adalah volume air yang ditampung pada hari akhir $\left(\mathrm{m}^{3}\right), \mathrm{V}_{\text {stored }}$ adalah volume air yang ditampung hari sebelumnya $\left(\mathrm{m}^{3}\right), \mathrm{V}_{\text {flow }}$ in adalah volume air yang masuk $\left(\mathrm{m}^{3}\right), \mathrm{V}_{\text {flow out }}$ adalah volume air yang keluar $\left(\mathrm{m}^{3}\right)$ dan $\mathrm{V}_{\text {seep }}$ adalah volume air yang hilang dari badan air $\left(\mathrm{m}^{3}\right)$.

\section{Tahap-tahap Pemodelan SWAT}

Model SWAT terdiri dari empat tahap, yaitu pembentukan delineasi wilayah, pembentukan Hydrologic Response Units (HRUs), pembentukan input data, serta proses kalibrasi dan validasi. Model ini menggunakan hydrologic response units (HRUs) yang terdiri dari beberapa input berupa peta tata guna lahan yang spesifik, peta jenis tanah, dan peta topografi. HRUs digunakan untuk menggam- 
barkan keragaman secara spasial dalam tutupan lahan, jenis tanah, dan kelas lerang di daerah aliran sungai. Tahap pertama, pembuatan delineasi wilayah dilakukan dengan memasukkan peta DEM DAS Ciliwung, menentukan jaringan sungai, menentukan outlet Stasiun Pengamatan Air Sungai (SPAS) Kampung Kelapa, dan menghitung parameter subDAS (Gambar 2). Delineasi wilayah dilakukan secara otomatis dalam model SWAT. Hasil delineasi ini berupa batas daerah tangkapan air situ yang terbentuk bernama subbasin, terbentuk juga jaringan sungai dan titik-titik outlet di setiap percabangan sungai yang ada.

Tahap kedua adalah pembentukan HRUs. Peta HRUs tersusun atas kombinasi tumpang susun peta tutupan lahan DAS Ciliwung tahun 2014 yang bersumber dari Badan Planologi Kehutanan Kementerian KLHK, peta DEM Ciliwung yang bersumber dari BPDAS Ciliwung Cisadane dan peta jenis tanah DAS Ciliwung dari Pusat Penelitian Tanah dan Agroklimat (Gambar 3). HRU yang terbentuk kemudian dikelompokkan di setiap wilayah subbasin.

Pembentukan HRUs yang secara otomatis dilakukan oleh SWAT, dilanjutkan dengan tahap ketiga, yaitu pembentukan input data. Input data SWAT untuk data generator iklim (weather generator data) dilakukan dengan memasukkan data-data iklim dari BMKG Stasiun Citeko tahun 2007-2017 yang meliputi data iklim, data curah hujan harian rata-rata, serta data suhu maksimum dan minimum harian rata-rata. Proses running model menggunakan input data curah hujan harian rata-rata selama 8 tahun (2008-2015) yang diperoleh dari enam stasiun, yaitu stasiun BMKG Citeko, Pos Hujan Gadog, Pos Hujan Gunung Mas, Stasiun Pengamatan Air Sungai (SPAS) Katulampa, Pos Hujan Depok UI, dan Pos Hujan Cibinong. Data yang sudah dibuat lalu dimasukkan ke dalam Weather Data Definition.

Tahap keempat yaitu proses kalibrasi dan validasi. Proses kalibrasi sangat diperlukan untuk mengukur tingkat keakuratan output yang dikeluarkan oleh model terhadap hasil observasi atau pengamatan lapangan. Kalibrasi model dilakukan dengan cara mengubah nilai parameter yang bersifat sensitif dan mempunyai pengaruh besar terhadap proses hidrologi yang diukur lalu simulasi kembali dilakukan untuk melihat perubahan output model yang terjadi dalam file rch. Perbandingan output debit hasil simulasi SWAT dengan debit hasil observasi di lapangan dilakukan dengan menggunakan kalibrasi manual (trial and error).

Metode statistik yang digunakan dalam proses kalibrasi dan validasi adalah model koefisien determinasi $\left(\mathrm{R}^{2}\right)$ dan model efisiensi (NSE) (Nash \& Sutcliffe, 1970). Kriteria nilai model efisiensi disusun oeh Motovilov (1999). Persamaan model yang digunakan adalah persamaan (2) dan persamaan (3).
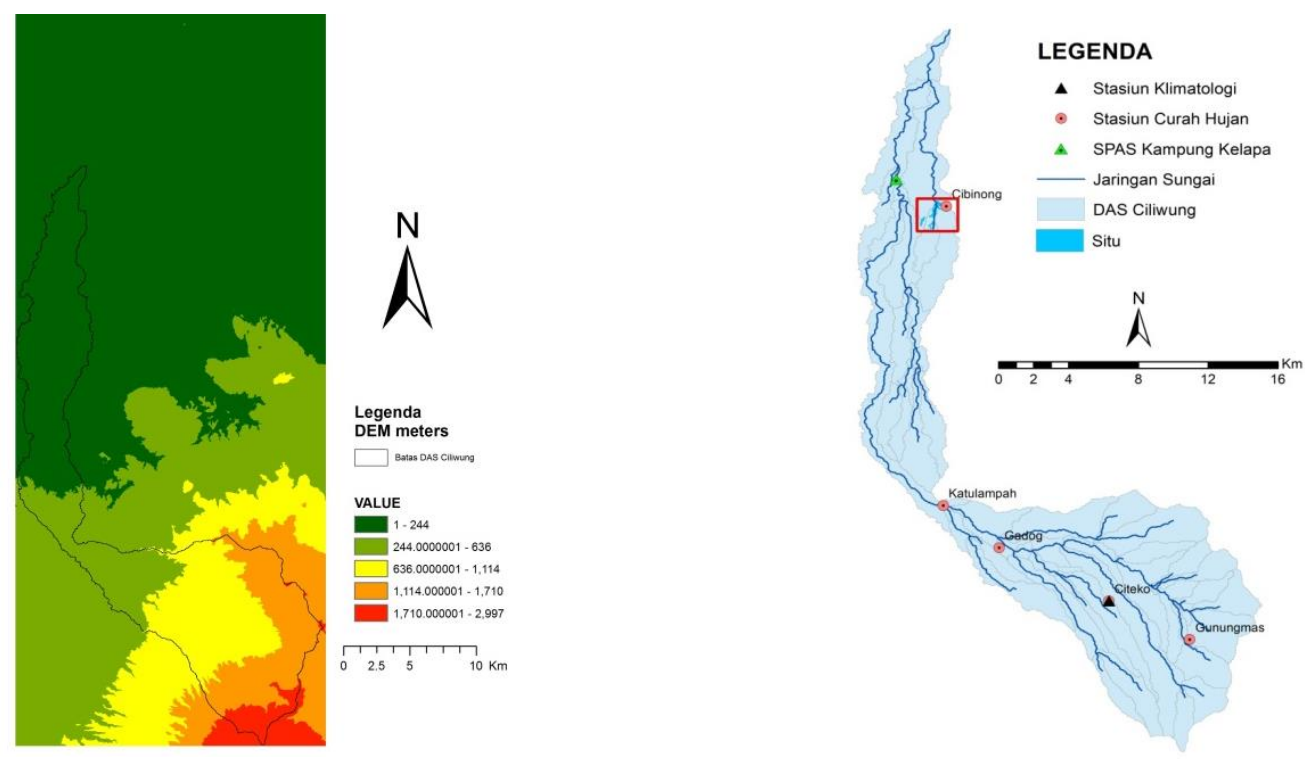

Gambar 2. DEM DAS Ciliwung dan lokasi stasiun iklim dan curah hujan 


$$
\begin{gathered}
\mathrm{R}^{2}= \\
{\left[\frac{\sum_{\mathrm{i}=1}^{\mathrm{n}}\left(\mathrm{Q}_{\mathrm{obs}, \mathrm{i}}-\overline{\mathrm{Q}}_{\mathrm{obs}, \mathrm{i}}\right)\left(\mathrm{Q}_{\mathrm{cal}, \mathrm{i}}-\overline{\mathrm{Q}}_{\mathrm{cal}, \mathrm{i}}\right)}{\sqrt{\sum_{\mathrm{i}=1}^{\mathrm{n}}\left(\mathrm{Q}_{\mathrm{obs}, \mathrm{i}}-\overline{\mathrm{Q}}_{\mathrm{obs}, 1}\right)^{2}} \sum_{\mathrm{i}=1}^{\mathrm{n}}\left(\mathrm{Q}_{\mathrm{cal}, \mathrm{i}}-\overline{\mathrm{Q}}_{\mathrm{cal}, \mathrm{i}}\right)^{2}}\right]^{2} \ldots \ldots} \\
\mathrm{NS}=1-\left[\frac{\sum_{\mathrm{i}=1}^{\mathrm{n}}\left(\mathrm{Q}_{\mathrm{obs}, \mathrm{i}}-\overline{\mathrm{Q}}_{\mathrm{cal}, \mathrm{i}}\right)^{2}}{\sum_{\mathrm{i}=1}^{\mathrm{n}}\left(\mathrm{Q}_{\mathrm{obs}, \mathrm{i}}-\overline{\mathrm{Q}}_{\mathrm{obs}, \mathrm{i}}\right)^{2}}\right] \ldots \ldots \ldots \ldots \ldots
\end{gathered}
$$

dengan $\mathrm{Q}_{\text {obs,i }}$ adalah debit observasi $\left(\mathrm{m}^{3} \mathrm{~s}^{-1}\right)$, $\mathrm{Q}_{\text {cal,i }}$ adalah debit simulasi $\left(\mathrm{m}^{3} / \mathrm{s}\right), \overline{\mathrm{Q}}_{\mathrm{obs}, \mathrm{i}}$ adalah debit observasi rata-rata $\left(\mathrm{m}^{3} / \mathrm{s}\right)$, dan $\overline{\mathrm{Q}}_{\text {cal,i }}$ adalah debit simulasi rata-rata $\left(\mathrm{m}^{3} / \mathrm{s}\right)$. Nilai $\mathrm{R}^{2}$ berkisar dari 0 sampai dengan 1 . Apabila nilai $\mathrm{R}^{2}$ semakin mendekati 1 , berarti terdapat hubungan yang erat antara data simulasi dan data observasi. Model Efisiensi merupakan suatu model statistik yang menunjukkan besar nilai pengaruh hubungan antara data simulasi dan data observasi. Nilai NSE berkisar dari 0 sampai dengan 1. Nilai NSE mendekati 1 menunjukkan bahwa performa suatu model baik (Tabel 1). Model statistik NSE ini paling banyak digunakan untuk menunjukkan performa suatu model karena dapat memberikan informasi yang lebih akurat mengenai nilai yang diberikan.

Tabel 1. Kriteria nilai model efisiensi dengan NSE

\begin{tabular}{lc}
\hline \multicolumn{1}{c}{ Kriteria } & \multicolumn{1}{c}{ NSE } \\
\hline Baik & NSE $\geq 0,75$ \\
Memuaskan & $0,36<$ NSE $<0,75$ \\
Tidak Memuaskan & NSE $\leq 0,36$ \\
\hline \multicolumn{2}{c}{ Sumber : Motovilov et al., 1999}
\end{tabular}

\section{Hasil}

\section{Delineasi SubDAS Cikumpa}

Deliniasi subDAS Cikumpa dilakukan secara otomatis menggunakan model ArcSWAT 2012. Dalam proses pembentukan subDAS, model SWAT menggunakan data berupa DEM DAS Ciliwung, batas DAS, dan outlet DAS. Pada penelitian ini ambang batas yang digunakan sebesar 250 ha, sehingga diperoleh 49 subbasin dan 1.102 HRU dari hasil delineasi DAS. Luas subDAS Cikumpa yang merupakan hasil delineasi DAS sebesar $2.520,90$ ha. Penggunaan lahan subDAS Cikumpa didominasi oleh permukiman, seluas $1.621,17$ ha $(64 \%)$ dari luas total subDAS. Pertanian lahan kering memiliki luas kedua terbesar, yaitu 860,85 ha $(34 \%)$, dan badan air (situ) menggunakan lahan terkecil, yaitu seluas 38,88 ha $(2 \%)$.

Bila dilihat dari Gambar 3, tanah di subDAS Cikumpa didominasi oleh jenis tanah latosol cokelat kemerahan dan latosol merah, seluas 971,00 ha $(37,73 \%)$ dan 860,49 ha $(33,44 \%)$. Jenis tanah kompleks aluvial cokelat dan aluvial cokelat keabuan memiliki luas paling kecil, sebesar 13,37 ha $(0,52 \%)$. Berdasarkan klasifikasi Kementerian Kehutanan, mayoritas kemiringan lereng subdas didominasi oleh tanah dengan kemiringan datar atau $0-8 \%(75,18 \%)$.

\section{Analisis Parameter Sensitivitas}

Analisis sensitivitas pada model hidrologi SWAT digunakan untuk mengetahui parameter-parameter yang paling berpengaruh terhadap output model sehingga hasilnya mendekati data observasi di lapangan. Arnold et al., (2012) menyatakan bahwa parameter sensitif digunakan dalam proses kalibrasi terkait aliran permukaan, di antaranya CN2 (SCS runoff curve number), kapasitas air yang tersedia dalam tanah (Sol_AWC), faktor evaporasi tanah (ESCO), faktor uptake tanaman (EPCO), koefisien lag aliran permukaan (SURLAG), dan nilai manning ' $n$ ' untuk overland flow (OV_N). Parameter yang sensitif dan berhubungan dengan baseflow antara lain ALPHA_BF, GW_REVAP, GW_DELAY, GW_QMN, REVAPMN, dan RCHARG_DP. 


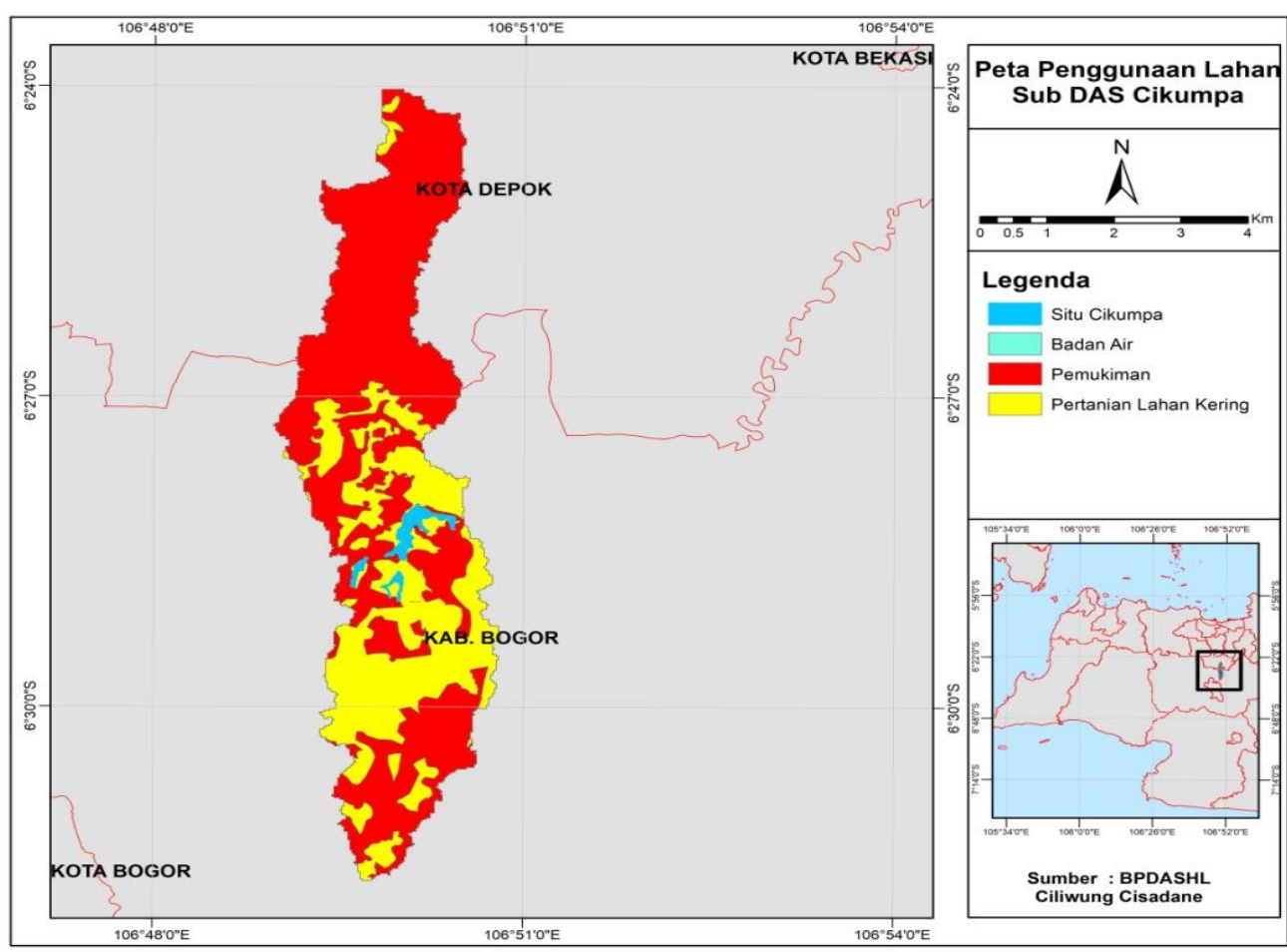

Gambar 3. Peta penggunaan lahan SubDAS Cikumpa

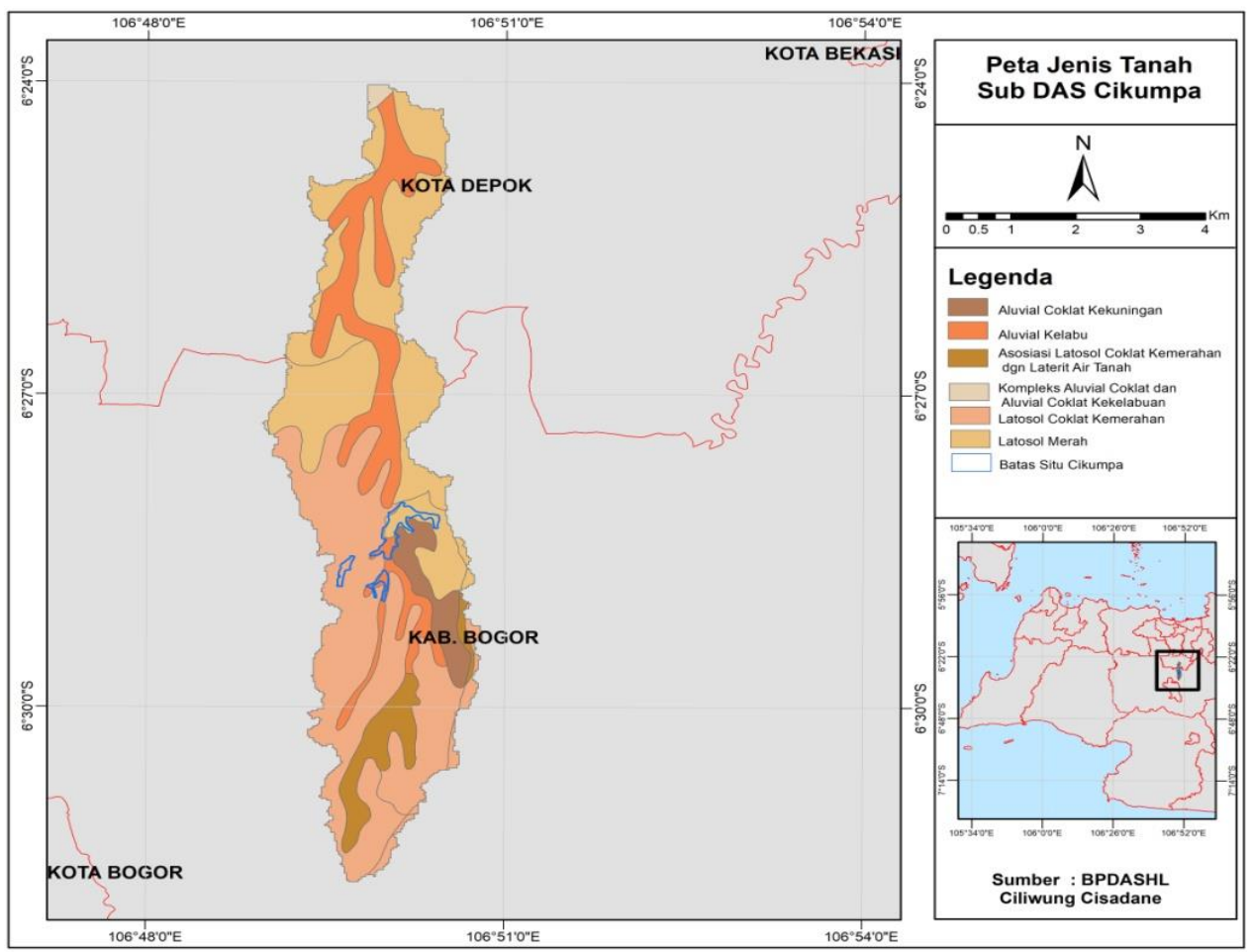

Gambar 4. Peta jenis tanah SubDAS Cikumpa

Parameter sensitif yang digunakan dalam proses kalibrasi di SubDAS Cikumpa (Tabel 2) adalah kedalaman permukaan air pada aquifer dalam (DEEPST), kedalaman permukaan air pada aquifer dangkal (SHALLST), koefisien lag aliran permukaan (SURLAG), ketinggian minimum aliran dasar (GWQMN), faktor uptake tanaman (EPCO), faktor evaporasi tanah 
Tabel 2. Parameter sensitif yang digunakan dalam kalibrasi model

\begin{tabular}{|c|c|c|c|c|c|}
\hline No & Parameter SWAT & Keterangan & $\begin{array}{l}\text { Nilai } \\
\text { Min } \\
\end{array}$ & $\begin{array}{l}\text { Nilai } \\
\text { Max }\end{array}$ & $\begin{array}{l}\text { Nilai yang } \\
\text { digunakan }\end{array}$ \\
\hline 1 & DEEPST & $\begin{array}{l}\text { Kedalaman permukaan air } \\
\text { pada aquifer dalam }\end{array}$ & 0 & 10000 & 4500 \\
\hline 2 & SHALLST & $\begin{array}{l}\text { Kedalaman permukaan air } \\
\text { pada aquifer dangkal }\end{array}$ & 0 & 7500 & 3000 \\
\hline 3 & SURLAG & $\begin{array}{l}\begin{array}{l}\text { Koefisien lag aliran } \\
\text { permukaan }\end{array} \\
\end{array}$ & 1 & 24 & 3 \\
\hline 4 & GWQMN & $\begin{array}{l}\text { Batas kedalaman air pada } \\
\text { aquifer dangkal yang } \\
\text { dibutuhkan } \\
\text { mengembalikan aliran }\end{array}$ & 0 & 7500 & 1500 \\
\hline 5 & ESCO & Faktor evaporasi tanah & 0 & 1 & 0.25 \\
\hline 6 & ALPHA_BNK & $\begin{array}{l}\text { Faktor alpha baseflow } \\
\text { untuk bank storage }\end{array}$ & 0 & 1 & 0.6 \\
\hline 7 & EPCO & Faktor uptake tanaman & 0 & 1 & 0.85 \\
\hline 8 & CH_N2 & $\begin{array}{l}\text { Nilai manning untuk } \\
\text { saluran utama }\end{array}$ & -0.01 & 0.3 & 0.015 \\
\hline 9 & CH_K2 & $\begin{array}{l}\text { Hantaran hidrolik di saluran } \\
\text { utama alluvium }\end{array}$ & -0.01 & 500 & 109 \\
\hline 10 & CH_K1 & $\begin{array}{l}\text { Konduktivitas hidrolik yang } \\
\text { efektif di saluran alluvium } \\
\text { sungai }\end{array}$ & 0 & 300 & 45 \\
\hline 11 & CH_N1 & $\begin{array}{l}\text { Nilai manning untuk } \\
\text { saluran sungai }\end{array}$ & 0.01 & 30 & 0.014 \\
\hline 12 & ALPHA_BF & Faktor alpha aliran dasar & 0 & 1 & 0.9 \\
\hline 13 & GW_DELAY & $\begin{array}{l}\text { Lama 'delay' air bawah } \\
\text { tanah }\end{array}$ & 0 & 500 & 31 \\
\hline 14 & REVAPMN & Perkolasi ke aquifer dalam & 0 & 1000 & 0.02 \\
\hline
\end{tabular}

(ESCO), nilai manning saluran utama (CH_N2), hantaran hidrolik pada saluran utama alluvium ( $\left.\mathrm{CH} \_\mathrm{K} 2\right)$, konduktivitas hidrolik yang efektif pada saluran alluvium sungai (CH_K1), nilai manning untuk saluran sungai ( $\left.\mathrm{CH}_{-} \mathrm{N} 1\right)$, faktor alpha aliran dasar (ALPHA_BF), faktor alpha aliran dasar untuk bank storage (ALPHA_BNK), lama air bawah tanah (GW_DELAY), dan perkolasi ke aquifer dalam (REVAPMN).

\section{Kalibrasi dan Validasi}

Kalibrasi debit dilakukan dengan membandingkan data debit hasil penghitungan model SWAT dengan debit observasi hasil pengukuran lapangan di SPAS Kampung Kelapa. Kalibrasi menggunakan data debit aliran tahun 2014 untuk periode harian dari tanggal 1 Januari sampai 31 Desember 2014. Sebelum kalibrasi dilakukan nilai kriteria model efisiensi yang ditunjukkan NSE sebesar 0,46 dan $R^{2}$ adalah 0,49. Selanjutnya, kalibrasi dilakukan dengan cara menyesuaikan titik tertinggi dan terendah, sehingga debit simulasi mendekati debit observasi. Neitsch et al. (2009) menjelaskan penyesuaian terhadap beberapa parameter perlu dilakukan untuk meningkatkan nilai NSE dan $\mathrm{R}^{2}$ agar mendekati debit observasi. Parameter disesuaikan secara manual atau coba-coba melalui trial dan error. Terdapat 14 parameter sensitif yang dikalibrasi dalam model SWAT (Tabel 1) untuk mendapatkan nilai NSE 0,55 dan $\mathrm{R}^{2} \quad 0,58$ (Gambar 5).

Validasi model dilakukan untuk menilai tingkat keakuratan dan konsistensi model dalam melakukan simulasi hidrologi. Proses validasi dilakukan dengan cara membandingkan data harian debit aliran observasi dari tanggal 1 Januari sampai 31 Desember 2013 dengan debit 


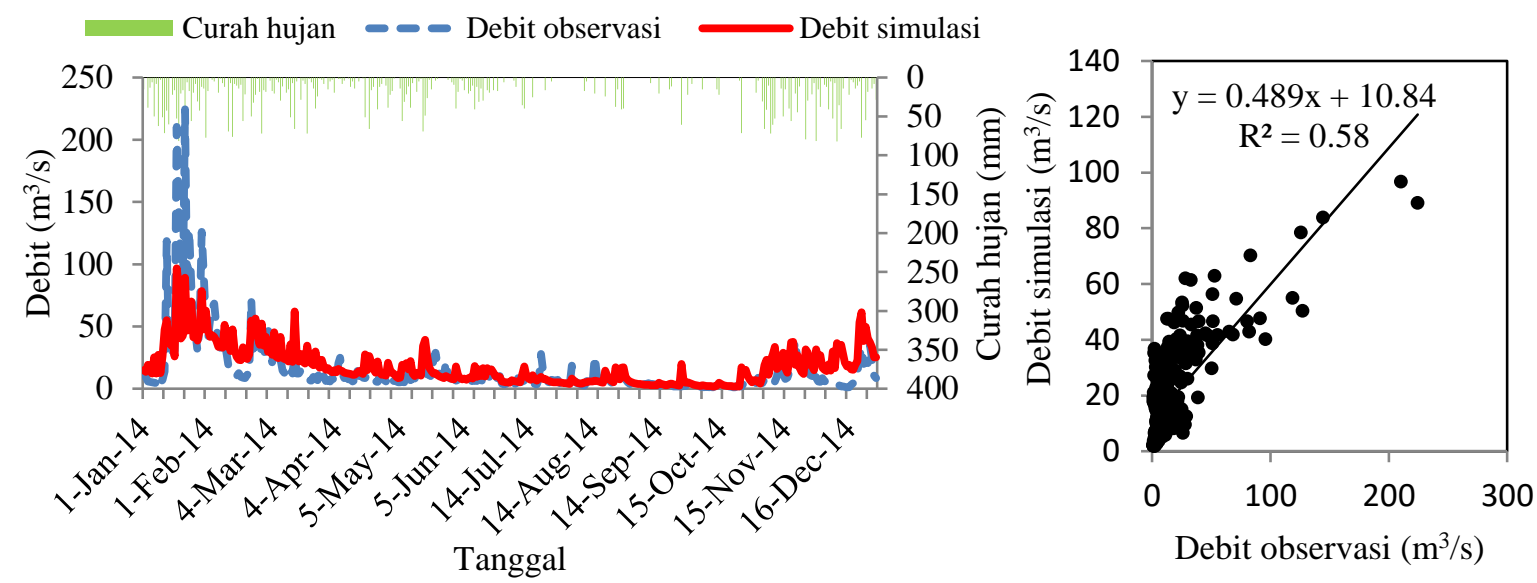

Gambar 5. Hidrograf aliran dan scatter plot hasil simulasi dan observasi setelah kalibrasi
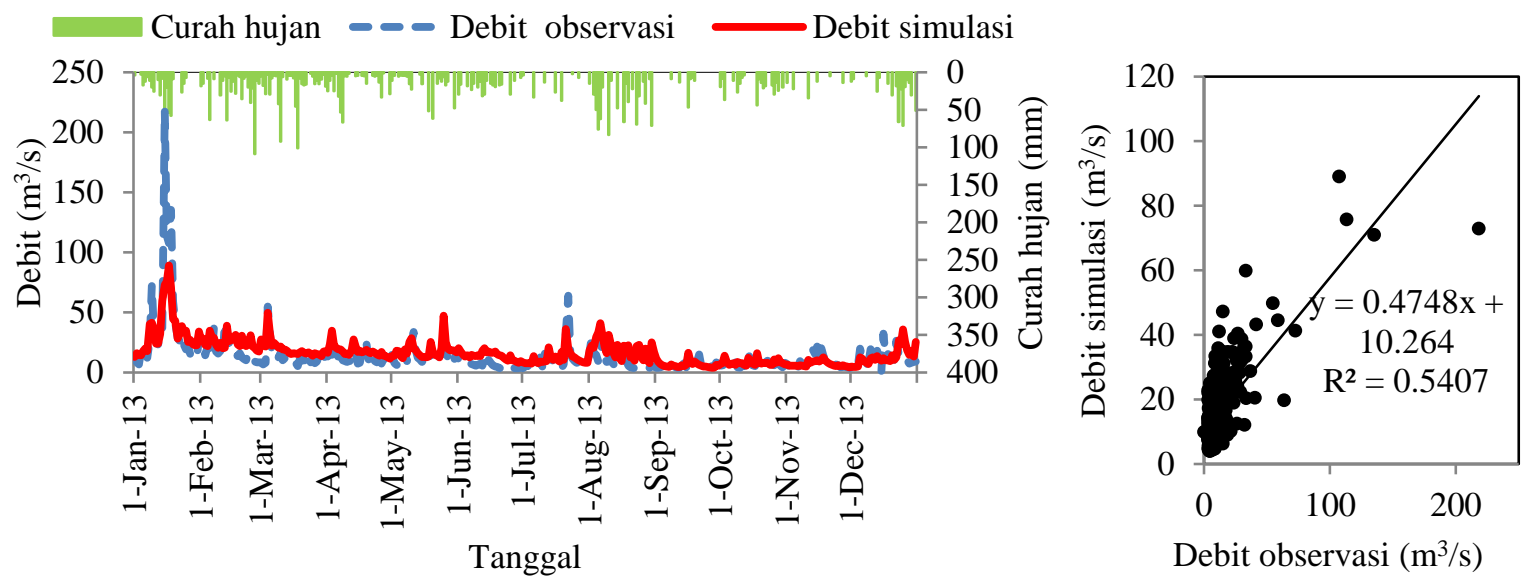

Gambar 6. Hidrograf aliran dan scatter plot hasil simulasi dan observasi setelah validasi

simulasi hasil model. Parameter yang dimasukkan menggunakan parameter sensitif yang didapatkan pada saat proses kalibrasi. Nilai NSE dan $\mathrm{R}^{2}$ yang diperoleh pada proses validasi sebesar 0,49 dan 0,54 (Gambar 6).

\section{Neraca Air Situ}

Parameter yang dipakai dalam pemodelan SWAT untuk menghitung neraca air adalah modul reservoir. Parameter input reservoir diambil berdasarkan data dari DED penggabungan Situ Kabantenan dan Situ Cikaret yang berasal dari BBWS Ciliwung Cisadane tahun 2015. Parameter input SWAT disesuaikan dengan kondisi Situ Kabantenan dan Situ Cikaret, antara lain bulan situ mulai beroperasi (MORES), tahun simulasi situ mulai beroperasi (IYRES), luas permukaan situ pada kondisi emergency spillway (RES_ESA), volume situ pada kondisi emergency spillway (RES_EVOL), luas permukaan situ pada kondisi principal spillway (RES_PSA), volume situ pada kondisi principal spillway (RES_PVOL), volume situ aktual (RES_VOL), awalan bulan pada hari/musim kering (IFLOOD1R), akhiran bulan pada hari/musim basah (IFLOOD2R), jumlah hari untuk mencapai target tampungan situ (NDTARGR). Parameter input SWAT untuk situ diperlihatkan dalam Tabel 3.

Komponen neraca air situ terdiri dari komponen input, yaitu curah hujan yang masuk ke situ (P), inflow dari sungai utama dan anakanak sungai (Qinflow) dan komponen output berupa evaporasi situ (Evap), outflow keluar situ (Qoutflow) dan Seepage situ (Seep). Prediksi neraca air rata-rata Situ Kabantenan 
Tabel 3. Parameter input SWAT untuk situ

\begin{tabular}{clccc}
\hline No & Parameter SWAT & Satuan & Situ Cikaret & Situ Kabantenan \\
\hline 1 & MORES & - & 1 & 1 \\
\hline 2 & IYRES & - & 0 & 0 \\
\hline 3 & RES_ESA & ha & 21,70 & 4,94 \\
\hline 4 & RES_EVOL & $10^{4} \mathrm{~m}^{3}$ & 72,26 & 16,45 \\
\hline 5 & RES_PSA & ha & 20,10 & 4,71 \\
\hline 6 & RES_PVOL & $10^{4} \mathrm{~m}^{3}$ & 45,23 & 13,99 \\
\hline 7 & RES_VOL & $10^{4} \mathrm{~m}^{3}$ & 45,23 & 13,99 \\
\hline 8 & IFLOOD1R & bulan & 4 & 4 \\
\hline 9 & IFLOOD2R & bulan & 9 & 9 \\
\hline 10 & NDTARGR & hari & 1 & 1 \\
\hline
\end{tabular}

Tabel 4. Komponen inflow dan outflow bulanan situ rata-rata tahun 2008-2015

\begin{tabular}{lrr}
\hline \multicolumn{1}{c}{$\begin{array}{c}\text { Komponen } \\
\text { inflow dan outflow }\left(\mathrm{m}^{3} / \text { tahun }\right)\end{array}$} & $\begin{array}{c}\text { Situ } \\
\text { Kabantenan }\end{array}$ & \multicolumn{1}{c}{$\begin{array}{c}\text { Situ } \\
\text { Cikaret }\end{array}$} \\
\hline Curah hujan & $145.750,52$ & 648.519 .64 \\
\hline Inflow dari daerah tangkapan situ & $5.505 .673,73$ & 24.693 .822 .41 \\
\hline Total input ke situ & $5.651 .424,25$ & 25.342 .342 .05 \\
\hline Evaporasi & 38005,24 & 166.542 .99 \\
\hline Outflow dari situ & $5.613 .344,04$ & 25.177 .593 .14 \\
\hline Seepage situ & 0 & 0 \\
\hline Output total dari situ & $5.651 .349,28$ & 25.344 .136 .13 \\
\hline
\end{tabular}

dan Situ Cikaret didasarkan pada hasil simulasi model dari tahun 2008 hingga 2015 (Tabel 4).

Estimasi curah hujan tahunan rata-rata yang masuk ke Situ Kabantenan selama kurun waktu 8 tahun sebesar 145.750,52 $\mathrm{m}^{3}$ dan inflow yang masuk ke situ dari aliran permukaan, aliran air bawah tanah, dan air lateral daerah tangkapan Situ Kabantenan sebesar 5.505.673,73 $\mathrm{m}^{3}$. Komponen air bawah tanah dan seepage sulit untuk diestimasi, sehingga nilai seepage yang dipakai dalam penelitian ini dianggap mendekati 0 . Estimasi curah hujan tahunan rata-rata yang masuk ke Situ Cikaret selama kurun waktu delapan tahun sebesar 648.519,64 $\mathrm{m}^{3}$ dan inflow yang masuk ke situ dari aliran permukaan, aliran air bawah tanah, air lateral daerah tangkapan Situ Cikaret sebesar $24.693 .822,41 \mathrm{~m}^{3}$.
Fluktuasi volume tampungan Situ Cikaret dan Situ Kabantenan selama kurun waktu delapan tahun diperlihatkan dalam Gambar 7. Dari hasil prediksi model, diketahui bahwa Situ Cikaret pada bulan Juli berada pada kondisi volume terendah dalam setahun, yaitu sebesar $463.844 \mathrm{~m}^{3}$ dan berada pada kondisi tertinggi pada bulan Maret sebesar $560.346 \mathrm{~m}^{3}$. Volume Situ Kabantenan pada bulan Januari berada pada titik terendah, yaitu sebesar $135.146 \mathrm{~m}^{3}$ dan bulan Juli berada pada kondisi tertinggi, yaitu sebesar $138.898 \mathrm{~m}^{3}$. Selama kurun waktu delapan tahun dalam rata-rata bulanan, volume kedua situ tidak pernah melebihi volume emergency spillwaynya, yaitu selalu di bawah $722.600 \mathrm{~m}^{3}$ dan $164.500 \mathrm{~m}^{3}$. 


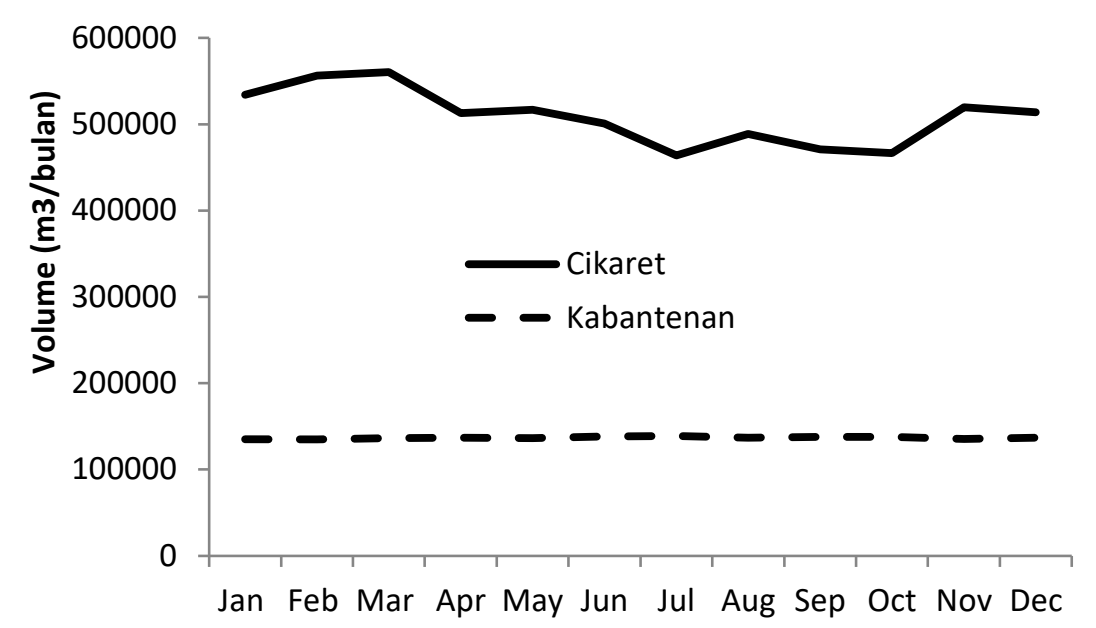

Gambar 7. Volume bulanan rata-rata tampungan Situ Cikaret dan Situ Kabantenan 2008-2015

\section{Pembahasan}

Hasil validasi model mencapai nilai NSE sebesar 0,49 dengan kategori memuaskan, walaupun nilai ini lebih rendah daripada hasil pemodelan di Ciliwung hulu yang mencapai nilai NSE 0,7 (Yustika, 2013). Perbandingan simulasi ini hanya dilakukan selama enam bulan. Nilai validasi ini juga lebih rendah daripada hasil pemodelan SWAT di Cisadane dengan nilai NSE 0,56 dan DAS Cimanuk hulu dengan nilai NSE mencapai 0,64 (Ridwansyah et al., 2014, 2012).

Situ Kabantenan mempunyai luas 4,94 ha atau hanya $23 \%$ dari luas genangan Situ Cikaret, sehingga hujan yang jatuh langsung juga hanya $23 \%$ dari Situ Cikaret (21,7 ha). SubDAS Situ Kabantenan merupakan bagian dari SubDAS Cikaret dengan luas 21,9\% dari luas total SubDAS Cikaret (543,74 ha). Akibatnya, fluktuasi volume tampungan Situ Kabantenan dan Situ Cikaret selama kurun waktu delapan tahun mempunyai pola yang berbeda, yaitu fluktuasi tampungan bulanan di Situ Cikaret lebih tinggi akibat aliran langsung yang masuk ke perairan Situ Cikaret. Hal ini tercermin dari inflow Situ Cikaret yang mencapai 4,5 kali dari inflow Situ Kabantenan, sehingga Situ Cikaret dapat berfungsi sebagai pengendali banjir seperti yang dinyatakan dalam penelitian Fakhrudin (2003) di Situ Cikaret menggunakan aplikasi pemodelan yang berbeda.

Pola fluktuasi tampungan Situ Cikaret juga mengikuti hujan bulanan rata-rata di SubDAS Cikaret. Hal ini tercermin dari hasil simulasi model yang memperlihatkan jumlah inflow bulanan rata-rata Situ Cikaret berkorelasi dengan jumlah curah hujan bulanan rata-rata yang masuk ke situ. Curah hujan bulanan ratarata meningkat dari bulan November hingga Februari dan kemudian mulai menurun dari bulan Maret hingga bulan Oktober. Dapat dilihat pula bahwa bulan Juli merupakan bulan dengan curah hujan bulanan rata-rata, inflow, dan outflow terendah sepanjang delapan tahun (2008-2015), sedangkan curah hujan bulanan rata-rata, inflow, dan outflow tertinggi terjadi pada bulan Februari.

Dalam penelitian ini kondisi masingmasing komponen neraca air juga dianalisis pada saat tahun kering atau kejadian Elnino pada tahun 2009, tahun basah atau tahun kejadian banjir, yaitu tahun 2013 dan tahun normal atau tahun 2010. Tahun 2013 dikatakan sebagai tahun banjir berdasarkan kejadian banjir di wilayah Depok akibat Kali Cikumpa meluap pada bulan Agustus 2013 (Pemerintah Kota Depok, 2013). Kejadian banjir tersebut terlihat dari kenaikan komponen neraca air Situ Cikaret yang signifikan dari bulan sebelumnya, terutama pada komponen inflow, outflow dan curah hujan yang masuk ke situ. Pada bulan Agustus tersebut juga terlihat bahwa terjadi kondisi surplus pada perubahan volume tampungan situ sebesar $5.954,84 \mathrm{~m}^{3}$ akibat inflow situ lebih besar daripada outflow situ.

Dari hasil simulasi dapat diketahui bahwa debit maksimum outflow Situ Cikaret selama tahun kering (2009), tahun normal (2010), dan tahun basah (2013) berkisar dari $1,00 \mathrm{~m}^{3} / \mathrm{s}$ sampai $11,12 \mathrm{~m}^{3} / \mathrm{s}$ dan tidak pernah melebihi 
debit maksimum spillway. Pada tahun basah, debit maksimum outlet terjadi pada bulan Februari 2013 sebesar $11,12 \mathrm{~m}^{3} / \mathrm{s}$, debit maksimum terendah terjadi pada bulan Juli, September, Oktober, dan November sebesar $1,00 \mathrm{~m}^{3} / \mathrm{s}$. Pada tahun kering, debit maksimum tertinggi terjadi pada bulan Maret sebesar 5,3 $\mathrm{m}^{3} / \mathrm{s}$, debit maksimum terendah terjadi pada bulan Agustus sebesar $0,62 \mathrm{~m}^{3} / \mathrm{s}$. Pada tahun normal, debit maksimum tertinggi terjadi pada bulan November sebesar $5,89 \mathrm{~m}^{3} / \mathrm{s}$ dan debit maksimum terendah terjadi pada bulan April, Juli, September, dan Oktober sebesar 1,00 m³ $/ \mathrm{s}$. Bila dikaitkan dengan kejadian banjir di Sungai Cikumpa, model SWAT telah berhasil menyimulasikan kejadian banjir pada tahun basah atau 2013. Hal ini terlihat dari debit maksimum yang terjadi pada bulan Februari 2013 sebesar $11,12 \mathrm{~m}^{3} / \mathrm{s}$ atau mencapai $60 \%$ dari debit maksimum spillway $\left(18,46 \mathrm{~m}^{3} / \mathrm{s}\right)$. Pada bulan Agustus 2013, debit maksimum outlet situ sebesar 7,14 m³ $/ \mathrm{s}$ atau $38 \%$ dari debit maksimum spillway. Kenaikan debit maksimum yang terjadi dikarenakan jumlah curah hujan pada bulan Februari dan Agustus yang tinggi sebesar $569 \mathrm{~mm}$ dan $746 \mathrm{~mm}$, sehingga debit sungai meningkat dan terjadi banjir di wilayah hilir Situ Cikaret.

Selama kurun waktu delapan tahun, baik Situ Cikaret maupun Situ Kabantenan tidak pernah melebihi volume emergency spillwaynya, yaitu selalu di bawah $722,600 \mathrm{~m}^{3}$ dan 164,500 $\mathrm{m}^{3}$. Volume maksimum Situ Cikaret mencapai 560,346 $\mathrm{m}^{3}$ dan Situ Kabantenan mencapai $138,898 \mathrm{~m}^{3}$, akan tetapi masih ada kejadian banjir di bagian hilir DAS Cikumpa pada tahun 2013. Padahal debit outflow hanya $60 \%$ dari debit maksimum., Hal ini kemungkinan disebabkan oleh kapasitas tampungan saluran yang kurang di bagian hilir DAS Cikumpa.

\section{Kesimpulan}

Hasil validasi model hidrologi SWAT untuk menyimulasi neraca air Situ Kabantenan dan Situ Cikaret pada kategori NSE memuaskan. Terdapat 14 parameter input SWAT yang sensitif terhadap debit aliran. Neraca air Situ Cikaret menunjukkan fluktuasi volume mengalami peningkatan dari bulan Agustus hingga Maret dan kemudian mulai menurun pada bulan April atau mulai bulan kering. Neraca air Situ Cikaret dan Situ Kabantenan selama kurun waktu delapan tahun simulasi tidak pernah melebihi emergency spillway di masing-masing situ, sehingga dapat digunakan sebagai salah satu pengendali banjir di DAS Ciliwung.

\section{Ucapan Terima Kasih}

Penulis menyampaikan terima kasih kepada Bapak Rizki (BBWS), Ibu Tika dan Hepy Hapsari (Bappeda Kabupaten Bogor), BPDAS Ciliwung Cisadane yang membantu dalam penyediaan data penelitian, serta Laboratorium Hidroinformatika Pusat Penelitian Limnologi LIPI yang menyediakan aplikasi ArcGIS, sehingga pemprosesan data penelitian dapat dilakukan dengan baik. Penulis juga mengucapkan terima kasih kepada Australia Indonesia Center (AIC) yang telah membantu peneliti dalam sebagian penggantian dana penelitian untuk pengumpulan data, sehingga penelitian ini dapat berjalan dengan baik., dan semua orang yang tidak dapat disebutkan satu per satu hingga penelitian ini selesai. Tulisan ini merupakan bagian dari penelitian mengenai keefektifan konsep perencanaan Situ Front City Kabupaten Bogor sebagai salah satu pengendali banjir di DAS Ciliwung.

\section{Referensi}

Arnold JG, Moriasi DN, Gassman PW, Abbaspour KC, White MJ, Srinivasan R, Santhi C, Harmel RD, Griensven AV, Liew MWV, Kannan N, Jha MK. 2012. SWAT: Model Use, Calibration, and Validation. American Society of Agricultural and Biological Engineers ISSN 2151-0032

Badan Nasional Penanggulangan Bencana (BNPB). Data Bencana Jakarta, Tangerang, Bogor Tahun 1996-2015. Diunduh 2016 Nov 18. Tersedia di http://dibi.bnpb.go.id/

Badan Pusat Statistik (BPS). 2016. Kabupaten Bogor dalam Angka. Bogor (ID): BPS Kabupaten Bogor

Fakhrudin M. 2003. Kajian Respon Hidrologi Akibat Perubahan Penggunaan Lahan DAS Ciliwung dengan Model Sedimot II. Thesis. Bogor (ID). IPB 
Firman T. 1997. Land conversion and urban development in the Northern Region of West Java, Indonesia. J Urban Studies 34(7): 1027-1046

Fletcher TD, Andrieu H, Hamel P. 2013. Understanding, management and modelling of urban hydrology and its consequences for receiving water: A State of the art. J Advance in Water Resources51: 261-279

Henny C, Meutia AA. 2014. Urban Lake in Megacity Jakarta: Risk and Management Plan for Future Sustainability. Procedia Environmental Sciences 20: 737-746. doi: 10.1016/j.proenv.2014.03.088

Henny C, Meutia AA. 2014. Water Quality and Quantity Issues of Urban Lakes in Megacity Jakarta. LIMNOTEK Perairan Darat Tropis di Indonesia 21(2): 145-156

[KLHK] Kementerian Lingkungan Hidup. 2014. Profil,Strategi dan Rencana Aksi Pelestarian Situ Jabodetabek. Jakarta (ID): KLHK

Kristiana. 2003. Kualitas Perairan Air Situ Gintung di Kabupaten Tangerang. [Skripsi]. Bogor (ID). IPB

Marwoto RM, Isnaningsih NR. 2014. Tinjauan Keanekaragaman Moluska Air Tawar di Beberapa Situ di DAS Ciliwung-Cisadane. Berita Biologi 13(2): 181-189

Motovilov YG, Lars G, Kolbjorn E, Allan R. 1999. Validation of a Distributed Hydrological Model Against Spatial Observations. J Agricultural and Forest Meteorology 98-99: 257-277

Nash J.E. and Sutcliffe J.V. 1970. River flow forecasting through conceptual models. Part 1. A discussion of principles. J. Hydrol. 10: 282-290

Neitsch SL, Arnold JG, Kiniry JR, Williams JR. 2009. Soil and Water Assessment Tool : Theoretical Documentation Version 2009. Texas (USA): Texas Water Resources Insitute-Texas A\&M University System Grassland, Soil and Water Research Laboratory-Agricultural Research Service; Blackland Research Center-Texas AgriLife Research

Pawitan. 2002. Hidrologi DAS Ciliwung dan Andilnya terhadap Banjir Jakarta. dalam: Pawitan H, (editor). Lokakarya Pengelolaan DAS Terpadu di Era Otonomi Daerah: Peningkatan Kapasitas Multipihak Dalam Pengendalian Banjir DKI Jakarta; Lembaga Penelitian IPB dan Andersen/Prasetyo
Strategic Consulting; 2002 Mei 8; Bappeda DKI, Jakarta, Indonesia. Bogor

Pravitasari AE, Saizen I, Tsutsumida N, Rustiadi E, Pribadi DO. 2015. Local Spatially Dependent Driving Forces of Urban Expansion in an Emerging Asian Megacity: The Case of Greater Jakarta (Jabodetabek). Sustainable Development 8(1): 108-119

Purnama RR. 2016. Rumah Terendam Banjir 2 Meter, Warga Depok Mengungsi. https://metro.sindonews.com/read/1092301/ 170/rumah-terendam-banjir-2-meter-wargadepok-mengungsi-1457712105

Remondi F, Burlando P, Vollmer D. 2015. Exploring the Hydrological Impact of Increasing Urbanisation on a Tropical River Catchment of The Metropolitan Jakarta, Indonesia. J Sustainable Cities and Society. 20 (2016): 210-221

Ridwansyah I., Pawitan, H., Sinukaban N., Hidayat Y. 2014. Watershed Modeling with ArcSWAT and SUFI2 In Cisadane Catchment Area: Calibration and Validation to Prediction of River Flow. International Journal of Science and Engineering 6(2): 12-21. Doi:10.12777/ijse.6.2.12-21

Ridwansyah I, Sapei A, Machmud A. Raimadoya. 2012. Applying SWAT to predict impact of landuse change on hydrological respone in upper Cimanuk catchment. Prosiding. The $5^{\text {th }}$ International Remote Sensing and GIS Workshop Series on Demography, Land use-Land Cover and Disaster

Rosnilla. 2004. Land Use Change And its Effect on the Lake's Existence: Case Study of Depok City.[Thesis]. Bogor (ID). IPB

Rustiadi E, Tarigan S, Nurholipah S, Pravitasari AE. 2012. Land Use/Cover Changes in Puncak Area (Upstream of Ciliwung River) and Its Potential Impact on Flood Dynamics. Towards Sustainable Land Use in Asia III. Hokaido (JPN): SLUAS Science Reports.

Schuler T, Simpson J. 2001. Introduction: Why urban lakes are different. Urban Lake Management. J Watershed Protection Techniques 3(4): 747-750

Setegn SG, Srinivasan R, Dargahi B. 2008. Hydrological Modelling in the Lake Tana Basin, Ethiopia Using SWAT Model. J Open Hydrology 2: 49-62

Sigh S, Kumar B, Thakural LN. 2009. A Comprehensive study on water balance, 
sedimentation and physico-chemical characteristics of Sagar Lake in India. $J$ Environmental Monitoring Assessment 148: 265-276. Doi:10.1007/s10661-008-0157-1

Steinberg F. 2007. Jakarta: Environmental Problems and Sustainability. $J$ Habitat International 31: 354-365

Supriyadi A, Syaufina L, Ichwandi I. 2015. Evaluasi Kebijakan Pengelolaan Situ Cikaret Kabupaten Bogor. LIMNOTEK Perairan Darat Tropis di Indonesia 22(1): 52-63
Wong THF, Breen PF, Somes NLG, Lloyd SD. 1999. Managing Urban Stormwater Using Constructed Wetlands. Australia (AU): CRC for Catchment Hydrology Industry Report Series.

Yustika D.Y. 2013. Simulation of Best Management Practices Using SWAT Model To Reduce Surface Runoff in Upper Ciliwung Watershed. Thesis. IPB 73 pages 